University of Louisville

ThinkIR: The University of Louisville's Institutional Repository

Electronic Theses and Dissertations

$5-2017$

\title{
Transplantar : los frutos de sus labores Transplant : fruit of their labor.
}

Marie-Elena Ottman

University of Louisville

Follow this and additional works at: https://ir.library.louisville.edu/etd

Part of the Fine Arts Commons

\section{Recommended Citation}

Ottman, Marie-Elena, "Transplantar : los frutos de sus labores Transplant : fruit of their labor." (2017). Electronic Theses and Dissertations. Paper 2665.

https://doi.org/10.18297/etd/2665

This Master's Thesis is brought to you for free and open access by ThinkIR: The University of Louisville's Institutional Repository. It has been accepted for inclusion in Electronic Theses and Dissertations by an authorized administrator of ThinkIR: The University of Louisville's Institutional Repository. This title appears here courtesy of the author, who has retained all other copyrights. For more information, please contact thinkir@louisville.edu. 
TRANSPLANTAR: LOS FRUTOS DE SUS LABORES

TRANSPLANT: FRUIT OF THEIR LABOR

By

Marie-Elena Ottman

B.F.A., University of Louisville, 2004

\begin{abstract}
A Thesis
Submitted to the Faculty of the

College of Arts and Sciences of the University of Louisville

In Partial Fulfillment of the Requirements

For the Degree of
\end{abstract}

Masters of Fine Arts in Studio Art and Design

Department of Fine Arts

Hite Art Institute

University of Louisville

Louisville, Kentucky

May 2017 
Copyright 2017 by Marie-Elena Ottman

All rights reserved 

TRANSPLANTAR: LOS FRUTOS DE SUS LABORES

TRANSPLANT: FRUIT OF THEIR LABOR

By

Marie-Elena Ottman

B.F.A., University of Louisville, 2004

A Thesis Approved on

April 24, 2017

By the following Thesis Committee:

Ché Rhodes, MFA, Principal Advisor

Margaret Leininger, MFA

Rachel Singel, MFA

Dr. Rhonda Buchanan 


\section{DEDICATION}

This work is dedicated to my husband

\section{Shawn Ottman}

and my children Logan and Elena.

You have encouraged me to continue and pursue my degree in

Masters of Fine Arts and without your patience,

and unconditional support

this would not have been possible.

Thank you and love you. 


\section{ACKNOWLEDGEMENTS}

I would like to express my gratitude to my Principal Advisor, Professor Ché

Rhodes, for his guidance, support and patience. I came into the glass world not knowing anything but cutting glass from a stained glass class taken over 20 years ago. Your invaluable expertise and willingness to allow me to experiment and grow as an artist is appreciated. I would like to thank Maggie Leininger for planting the seed in the vast world of fibers. I have learned so much from you and I truly appreciate your effort and guidance. Also, I would like to thank Rachel Singel who is filled with great energy and passion for printmaking. You have encouraged me to continue exploring this medium even though I have just begun to scratch the surface. In addition, I am grateful to all the art professors from the Fine Arts Department who have welcomed me and addressed my questions, concerns and offered advice as an art student. I also would like to thank Dr. Rhonda Buchanan for her encouragement to pursue the Graduate Certificate in Latin American and Latino Studies and celebrated the bilingual book art project and allowed me to see it come to fruition with the children at Doors to Hope. Finally, I would like to thank my parents for believing in me and encouraging me along the way, especially on those days that I needed that extra push and helping me with the care of my children. Thank you Dad y gracias Mamá por todo! 


\title{
ABSTRACT \\ TRANSPLANTAR: LOS FRUTOS DE SUS LABORES TRANSPLANT: FRUIT OF THEIR LABORS
}

\author{
Marie-Elena Ottman
}

April 24, 2017

This thesis will describe my body of work both formally and conceptually and accompanies my thesis exhibition. In the Introduction section, I will discuss my influences and the forms that I am exploring in creating this body of work and the experience that provided me with first-hand knowledge that pertains to immigrants. In Methods and Materials, I will discuss the materials that I used, glass, ceramics and metal. I will separate the glass and ceramics in two categories as each material was handled differently. I will also touch on the metal frame that is utilized to suspend the forms. In Concept and Artistic Influences, I will discuss the concept for this body of work, my experiences that contributed to the work, and I will explain in chronological order the individual sculptures, as well as touch on my artistic influences that informed my work. In the Conclusion, portion I will discuss how my experience in the graduate program has influenced my work and the direction I see myself taking artistically in the future. 
TABLE OF CONTENTS

Page

APPROVAL PAGE

iL

DEDICATION

IIL

ACKNOWLEDGMENTS

Lv

ABSTRACT

$\mathrm{V}$

SECTION

$\begin{array}{ll}\text { I. INTRODUCTION } & 2\end{array}$

II. METHODS AND MATERIALS 5

III. CONCEPT \& ARTISTIC INFLUENCES 12

$\begin{array}{ll}\text { IV. CONCLUSION } & 20\end{array}$

$\begin{array}{ll}\text { REFERENCES } & 21\end{array}$

$\begin{array}{lr}\text { CURRICULUM VITA } & 22\end{array}$ 


\section{INTRODUCTION}

Manual: man·u·al \'man-yə-wəl, -yəl, -yü-əl\

a: of, relating to, or involving the hands manual dexterity

b: worked or done by hand and not by machine

c: requiring or using physical skill and energy

Labor: la·bor \' lā-bər\

a: human activity that provides the goods or services in an economy, Industry needs labor for production

The cultural origins of many manual laborers and immigrants who work in the industry and field cultivating and harvesting food are devalued in our society, however, the consumption of exotic ethnic foods is popular. Many of these foods are from the same origins as the immigrant laborers. Most of these foods have been stripped of their ethnicity due in part from popular cultural trend and instant gratification.

In today's society the desire to perform manual labor, specifically in agriculture, is slowly becoming a thing of the past and its placement of value is in the lowest social class. I have placed the Merriam-Webster definition of manual labor front and center in my Artist Statement as a reminder of what it means. Society has become disconnected with the effort involved in the cultivation and harvesting of fruits and vegetables because we have become so accustomed to the ease of attaining them at the grocery store. This instant gratification has blinded us to the invisible workers in the fields, many of whom are immigrant workers who are grateful for the opportunity to work.

My work stems from an interest in botanical forms found in nature and for this project I explored the metaphorical potential of the vine, coconut, cashew fruit and cacao pods as vehicles to express various multi-cultural themes, such as: language barriers, the migration journey, and manual labor by immigrants and others. Translating on behalf of 
my Panamanian mother for the majority of my life, interpreting as a Qualified Court Interpreter for the State of Kentucky, and teaching English as a Second Language are all experiences that have provided me with firsthand accounts of the hardship and struggles that immigrants endure as they acculturate to their new home. After serving as a conduit for their voices for years, I feel compelled to utilize my voice and this platform to shine a positive light on their hard work in order that they may garner respect for their sacrifices that allow us to enjoy the literal fruits of their labor.

The materials for this body of work are metal, blown glass and hand cast ceramics. As crafts, these materials are labor intensive, but are also considered by many to be in the lower portion of the "fine art" spectrum. The coconut, the cashew fruit, and the cacao pods were conceptually driven because they are all indigenous to the tropics and can only be harvested by hand. The United States is one of the largest consumers of cashew nuts, chocolate, and coconut, particularly coconut oil and coconut water. Although the coconut can be grown in warmer climates in the United States, it too is symbolic of the migratory journey because it is a self-contained vessel that travels ocean currents to reach new soil.

The metal organic forms symbolize a vine and the concept of living as a transplant in the United States. Vines that grow in the rainforest have very shallow roots and do not require the roots to be very deep in order to survive. As the vine grows longer and longer and gets farther away from its roots, it still draws nutrients from its origin, a parallel that can be made with the lives of immigrants. Even though they move farther away from their native country, they are still nurtured by their culture through language, rituals, and foods. Like a vine, the migration journey is not a straight path. The twists 
and turns in the growth of the vine mirror the multiple directions an immigrant will traverse during their migration.

The omission of colors for what are normally brightly and beautifully colored cacao pods, cashew fruits, and coconuts is an intentional whitewashing to emphasize that with the purchase and consumption of ethnic foods, the origins of these goods are often ignored. Other elements that are missing from the three fruits are the nuts and nibs. The fruit from the cashew and cacao is edible and delicious, and therefore valuable, but is often discarded. The seed on the exterior of the cashew fruit is visible, but the actual cashew nut lies inside the seed and is therefore invisible. This invisibility metaphorically symbolizes the many immigrants whose work in the fields is so often not appreciated by those who enjoy the fruits of their labor. 


\section{METHODS AND MATERIALS}

I took into consideration the materials that I worked with to create this body of work and I chose to combine ceramics and glass together. The sculpture Poco a poco se raya el coco - Little by Little the Coconut is Shred, was created at the Cressman Center and was the first sculpture for my body of work, Transplante: Los frutos de sus labores /

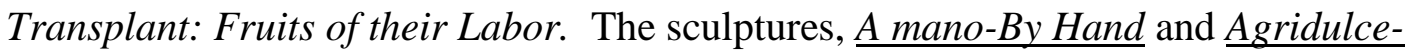
$\underline{\text { Bittersweet }}$, were created simultaneously. Some days were spent in the hot shop at the Cressman Center blowing glass, finishing and polishing and other days I was in my studio casting ceramic, finishing and glazing. Both of these materials are labor intensive and one that require a substantial amount of manual labor to produce the volume of work I needed for the sculptures. I will discuss both materials separately and discuss my process.

I chose to work with a low-fire, white earthenware for a couple of reasons. Earthenware is clay that was originally used by the indigenous people of the Americas. They had access to this clay, mined it and used it for various utilitarian and ceremonial purposes. Immigrants working in the field are, for the most part, descendants of indigenous groups from their corresponding countries. I am making a symbolic connection with the earthenware clay used by indigenous people and migrant workers in the field.

I also chose to work with a white earthenware as opposed to a porcelain clay body because the white earthenware is valued the least. White earthenware is commonly used 
in the hobby ceramics industry and is used to slip cast kitschy molds and is fired at a low temperature of approximately 1800 degrees Fahrenheit. It usually is not fired to maturity or to a vitreous state, and requires an application of glaze. Porcelain is the most esteemed material in ceramics and is considered the most valuable because the clay body by itself produces a bright white finish and when fired to maturity is completely vitreous. It is also more challenging to manipulate and the firing temperature is higher, approximately 2100 degrees Fahrenheit. By consciously choosing the least valuable ceramic material, I am emphasizing the undervalued manual laborers whom society views to be in the lowest social class, particularly those who work in the fields. These workers are undervalued within our society when in reality they are invaluable.

I wanted to create a large volume of cashew fruits and cacao pods in various sizes ranging from small, medium and large. This volume of work would give it presence and visually depict a form that emulated growth. I hand formed and sculpted each cashew fruit out of ceramics using real cashew fruits as my model. I was able to locate frozen cashew fruits in a Mexican grocery store in the freezer section. I made ten slip cast molds in sets of two ranging from large to small, out of plaster. The plaster absorbs the moisture from the slip and allows the clay to harden to the shape of the inside of the mold. I placed all the molds on a pour table in assembly line from large to small. I poured the ceramic slip into the molds and topped off the molds every few minutes to ensure the molds were full. I calculated the cast time for each cashew fruit to be approximately twenty minutes. I had a timer scheduled for twenty minutes, and as I was waiting for the molds to set up, I worked on the cashew fruits that were in the greenware stage by plugging the pour hole, cleaning the seam lines and inserting a high fire 
nichrome wire in a u shape to create the hanger. When the timer went off, I dumped the slip in the slip containers and placed the molds upside down for the slip to drip into the pour table and allowed the molds to set up. The cast ceramic would set up and would be ready for removal from the mold in four hours. I would repeat this process up to three times per day as the molds could only cast so much before the plaster would become too water logged and not cast effectively. I did the same procedure with the cacao pods and produced until I had the amount needed.

By setting up my studio as a small production facility of ceramic cashews and cacaos, I created an environment similar to that of the cashew and cacao factory workers. I was creating work that was repetitive in nature similar to the cashew and/or cacao factory. Their work is often time very repetitive and requires long hours. I became quicker and more efficient the longer I worked in this environment, similarly, the cashew and cacao workers improve their methods and acquire a quicker pace. This is important as the cashew workers only get paid per amount of nut extracted (Carr), or in the case of the cacao laborers, per bag of cacao beans (Leissle).

Once the greenware was bone dried and ready to be fired, I placed it in the kiln and fired the greenware to a bisque firing of 1943 degrees Fahrenheit. I glazed the cashew fruits with a satin glaze to give them a waxy, fruit finish and fired them to 1828 degrees Fahrenheit. I used fruit boxes I collected from the grocery stores to transport the greenware and bisques back and forth from my studio to the kiln. I often thought about how the laborers used these same fruit boxes to transport the fruits from the farm to the grocery store. 
For the glazing portion of my work, I lined the tables in my studio with a wire rack in preparation for glazing all the fruits and pods. I hand dipped all the forms into a clear glaze. The wire racks allowed the air to circulate underneath them and gave room for the glaze to drip dry. I used two different clear glazes because I was after a certain aesthetic with each form. For the cashew fruit, I used a low fire satin glaze from Mayco and for the cacao pods, I used a low fire matt glaze from Duncan. Both of these glazes were fired to 1828 degrees Fahrenheit. Once the glaze firing was complete, I unloaded the kiln. I had to place the glazed forms on stilts so they would not stick to the kiln shelves. There were stilt marks on the forms that had to be removed. I used a dremel tool to remove the stilt marks on the forms and waxed those areas to complete the piece.

Working with glass, as I mentioned before, requires a substantial amount of manual labor and it is necessary to depend on a partner to blow glass. The transparency of the glass is what attracted me to this medium and I am exploring this quality because it allows me to traverse metaphorically back and forth between my two cultures, Panamanian and American. Working with glass was a different process as I created all the forms in the hot shop at the Cressman Center. I created one blow mold of the coconut form and multiple blow molds, from large to small, of the cacao forms. The blow molds were constructed using plaster and I would store the blow molds in a plastic bag to prevent the molds from drying out. This method is different from the ceramic slip molds because those molds had to be completely dry in order to ensure a nice slip cast.

For the first blow mold I created, I used an actual coconut, covering it with Murphy's Oil and making a two part plaster mold from it. The coconut blow mold was a large size and required three gathers of glass. My routine for blowing the glass coconuts 
and cacao pods are as follows: I heat the blow pipe in the glory hole, blow into it to ensure the pipe is clear, then gather glass at the glass furnace, marver, shape it, and blow a bubble into the glass. I let the glass cool down just a bit and return to the glass furnace for the second gather. I would walk to the watering pump and cool the pipe before sitting at the bench for shaping. After the third glass gather, I used the wood block to shape the glass and had my glass partner blow into the pipe as I placed a jack line on the glass close to the end of the pipe. A jack line is a line created with either a jack, a large shaped tweezer, or a diamond shear to mark the point where the glass will be separated from the blowpipe or pontil. I reheated the glass in the glory hole, heating the glass to the point that it was moving around on the blowpipe. I gently swung the pipe back and forth and allowed gravity to shape the form into a more oblong shape. I quickly stepped up on the bench and placed the hot glass into the mold where my partner would close the other half of the mold. I would then blow the form until it filled the cavity of the mold. Once the glass took shape of the mold, I flashed the glass in the glory hole and then knocked the coconut or cacao into an annealing kiln. I continued this process until I reached the desired amount of forms. The other coconuts that were medium and small, were hand manipulated into the forms using a wet newspaper.

For the cacao forms, I made three blow molds, a large, medium and small. I used an actual cacao pod that I purchased from a cacao farm in Ecuador. I did not want to damage the real pod, so I hand formed the pod out of clay and used the real pod as my model. With these blow molds I applied a light coating of powdered graphite inside the molds to help protect them. Once all the glass forms were annealed, I would use the belt sander and smooth out the openings of the coconuts and cacao pods. After sanding and 
shaping the openings of the glass forms, I sandblasted them, followed by polishing the glass using a wax to bring out a sheen and finish the piece. I had to create hooks on the openings of the glass using a two part epoxy clay because I was not able to insert high fire wire hooks in the glass as I did with the ceramic forms. I formed wire hooks and epoxied the wire and sealed the openings of the glass forms with the epoxy clay.

To create the glass cashew seed, I opted to hand form the seeds instead of using a mold for several reasons. I wanted to create a variety of sizes because the true cashew seeds come in different sizes depending on the growth of the fruit. By sculpting each one, I was able to create the variety I needed. It also required me to do manual labor by hand forming approximately 250 glass cashews. As I was forming each one, I became more proficient and my partner and I were setting up a good pace. It also required me to learn a new technique in hot glass, sculpting with hot glass, using tools to manipulate the form proved challenging for me. I worked with a glass partner and it took us several attempts and different tools until we came up with a method that was efficient for both of us. I would gather the glass using a pontil, dipping it into the glass furnace once or twice, depending on the size of the seed required. I rotated the glass using gravity to center it on the pontil. I sat at the bench and stopped rotating the glass while I placed the flat tweezer up in the glass, allowing the glass to slump over the tweezer. Once I got the desired shape, I used the diamond shears and placed a jack line between the end of the pontil and the glass. I used the flat tweezers and gently pinched and shaped the seed into its final form. I would pass the pontil to my glass partner and he provided me with a new pontil. He would take the pontil with the seed and knock it into the annealing kiln while I started gathering glass and repeated the process. When the glass cashew seeds were annealed, I 
finished the ends on a glass grinder and then polished and attached to the ceramic cashew fruit with a glass adhesive.

Working quickly and repetitively, laborers in the fields become adept at harvesting several fruits at a time by hand, which is crucial because they only get paid per bin or bushels and not as salaried employees. Not only do they work long hours, their bodies will eventually start to take a toll doing this type of work with constant repetition and heavy lifting. (Smiley)

I worked with FirstBuild and had them fabricate the metal pipes for my sculptures. I met with the fabricators and I showed them a small wire prototype. This prototype was a visual of the twists and bends I wanted to achieve with the pipe. After discussing with the fabricators, it was concluded that some of the tighter bends that I had on my prototype would not be possible due to the limitations of their equipment. I compromised and explained I needed my pipes to have an organic shape that would emulate a vine structure. I watched as the fabrication was taking place and I gave input as to adding more bends but essentially without being committed to a prototype, we allowed the equipment and the pipe to evolve into the organic forms. We discussed options for anchoring the work and took into consideration the weight of each work. Ultimately we decided on the welded circular disk at the end of the pipes to be used as an anchoring mechanism on the wall. 


\section{CONCEPT AND ARTISTIC INFLUENCES}

The concept for Transplante: Los frutos de sus labores / Transplant: The Fruits of their Labor originated quite simply by mere observation. My ethnic background and observation through an outsider's lens made me more aware of the stereotypes that are prevalent in today's society. From my observations, I found it ironic that someone can consume ethnic food and between forkfuls of food spew degrading comments about that particular ethnic group. There are no borders or walls when it comes to eating ethnic or exotic food. The more exotic the ingredient, the more valuable it becomes.

Food is powerful. It not only nourishes our bodies, but for most immigrants, it is what connects them to their culture and brings them comfort. This is one of the reasons we have so many restaurants offering comfort food from all nationalities. Many immigrants who have migrated to the United States arrive with their favorite recipes from home and quite a few restaurants got their beginnings preparing food from their country. If when preparing a cultural dish one cannot obtain a specific ingredient, it is substituted with an ingredient that is similar. These substitutions within a certain special cultural dish meld with ingredients that at one time were unfamiliar, thus creating a new version of this cultural dish. This dilemma is slowly disappearing as more grocery stores and online stores are carrying a wider range of ethnic foods, which have become a popular cultural trend that one can see first-hand at the local grocery store. There are sections dedicated to ethnic foods from different countries and the sections appear to be growing. 
At one time, if a specific ethnic ingredient was needed for a dish, one would have to go to a specialty grocery store that catered in ethnic foods.

This vein of thought led me to the disconnection that society has with the origins of our produce. The abundance of fruits and vegetables and the ease of accessibility have been taken for granted. We do not have to worry about where our food comes from. We go to the grocery store and get what we need and want. At one time the only produce that was available was locally grown. It used to be that one would have to wait for the seasons in order to get certain fruits and vegetables. Due to food being imported nationally and globally, one no longer has to wait for the seasons in order to enjoy certain foods. Any locally grown produce is available throughout all seasons.

My artistic influences during graduate school focused on organic and natural forms that originated from the tropics. I explored the forms from the Oropendola bird's nest that are found in Central America. The weaving and scale of these nests from these birds impacted me. I was intrigued, and still am, with the Liana vines that grow in the tropics. These vines are large and woody and have a lyrical quality about them and they continue to be a part of my current work. While researching these vines, I came across Henrique Oliviera, an artist from Brazil who creates larger than life sculptural forms out of plywood and PVC recycled from dumpsters. His forms reminded me of those vines and I really gravitated to his application of colors on the forms (Keiren).

I also was drawn to the sculptures by Ruth Asawa. Viewing her sculptures in person at the San Francisco Museum of Fine Arts and being able to see the intricate wire 
weavings opened my eyes to the possibility of what can be created using wire. I found it interesting that she went to Mexico and studied the art of basket weaving and used the skills she learned to form her own aesthetic. She is better known for creating her large scaled crotched wire sculptures in organic shapes.

I am not partial to one specific medium and I enjoyed working and learning about different mediums such as glass, fibers and printmaking. However, glass captured my attention throughout my schooling. There are many avenues in the glass medium that I will continue to explore and am looking at various glass artists, several of whom came to the Cressman Center, such as visiting artists Carmen Lozar, Benjamin Wright, Shane Fero, and Judy Schaechter. The visits from the artists were invaluable and left an impression on me. The opportunity to be able to communicate with them one on one was a great experience. The variety of work and style that can be created using glass as a medium is immense.

During my graduate studies I also was presented with various artists whose concepts were based on social commentary art and these studies resonated with me and helped take me in that direction for this body of work. There were a couple of artists that intrigued me, such as Julie Green, a painter who was compelled to create a whole series of hand painted food objects on white stoneware depicting the last supper requests by U.S. Death row inmates. She came across this subject by reading an article and wondered why an inmate's last meal request is a tradition. Her concept was formed after 
reading in the newspaper about an inmate's request for six tacos, six glazed donuts, and a cherry coke (Johnson).

Doris Salcedo is an artist from Colombia and her social commentary was based on the research she had done regarding the disappearance of women and the violence against these women. In most cases, these women's shoes were what was left behind and was used to identify the victims. She created a series of shoe boxes fabricated from stretched animal fiber and placed the used women's shoes inside the boxes, along with empty boxes, which represented the future victims (Grynsztejn).

Poco a poco se raya el coco - Little by Little the Coconut is Shred

One of the most difficult things to interpret without losing meanings are idioms. This idiom is very common in Panama. My mother repeatedly told me this throughout my life. The literal translation of "poco a poco se raya el coco" is "little by little the coconut is shred." The closest idiom in English that would encapsulate the meaning of the idiom is: "slow and steady you win the race." The coconut is a hard fruit to open because it has several layers before reaching the actual nut. Once you get to the layer where the nut is contained, you have to crack that nut open which is not easy. Once the nut is cracked, you have access to the coconut meat, which then you have to shred, a time consuming operation.

This idiom is about perseverance and not giving up because little by little you will achieve what you have set out to accomplish. The reward is the meat of the coconut. The coconuts on the sculpture are arranged on a vine like structure with the largest at the top. 
The largest coconut reached maturity and is ready to be taken down to start the hard process of breaking into the coconut. As you are busy breaking the large mature coconut, you have all these other coconuts in different growth stages lined up to signify the importance of not resting on your laurels. The large coconuts metaphorically symbolize the present while the other coconuts in their various stages symbolize the future.

When thinking about this idiom, I connected it with the hard work and the effort that many immigrant laborers endure. Little by little they pick the fruit, little by little they pick the vegetables, and little by little their dreams and their children's dreams will come to fruition.

The coconut is also symbolic in the migratory journey as the coconut seed floats and is transported via the ocean currents (Tanabe). It self-propagates and can easily grow in the right climate which is usually in the tropics.

\section{$\underline{\text { A mano }- \text { By Hand }}$}

The cashew fruit is originally from Brazil and the Portuguese traders brought this tree to India. India exports the largest volume of cashews along with other tropical countries. (Palermo) The tree is adaptable and grows easily in poor soil and matures quickly.

The cashew fruit is technically a pseudo fruit because the seed is contained on the exterior of the fruit, and as the stem matures, it swells into the fruit. Harvesting the cashews is labor intensive and can only be harvested by hand. The fruit is actually very

delicious but is too complicated to process. It starts to deteriorate once it is plucked from 
the tree and the outer skin of the fruit is so delicate that is damages easily. The actual cashew nut is the most valuable part on the fruit, so essentially, the fruit is discarded and only the seed is retained.

The cashew tree is related to poison ivy and the seed is encased in an oily resin, anacardic acid, and causes rashes and blistering if exposed to the skin. (Palermo) The seed of the cashew is very hard to crack. It's not like a walnut which can be cracked with a tool. The seed needs to be boiled or roasted over fire in order to crack open. Larger factories use two methods to extract the nut. They either roast the seeds in large barrels or they boil them. For personal consumption the seeds are usually roasted outdoors and precaution is taken not to inhale the smoke because it can cause a severe reaction as the resin drips into the flame. When handling the cashew seeds, the workers usually rub their hands in coconut or Castrol oil. Sometimes they wear gloves but they find that this can hinder their speed in cracking the seed and getting the cashew nut and usually opt for rubbing the oil on their hands. Every aspect of harvesting the cashew is carried out by hand, with the exception of a little mechanical tool that cracks the exterior of the shell. The cashew nut is then slightly roasted to ensure that the resin is completely removed from the nut. It is then sorted by size and packaged. (Carr) Essentially, every cashew that we eat has been touched by hand.

The use of the cashew fruit symbolizes the migration, as it traveled from Brazil to India. It is hardy and adaptable similar to immigrants. The cashew fruit is edible and delicious but is discarded due to the difficulty in processing, thus making the seed more 
valuable. Similarly, the value of the manual labor performed by field workers is considered the lowest in the social class. The visual growth stages of the cashew from small to large metaphorically symbolize the growth that an immigrant undergoes while acculturating and adapting to their new surroundings.

\section{$\underline{\text { Agridulce-Bittersweet }}$}

The cacao has its origins from Mexico and during the Mayan period, the cacao beans were used as currency. For example, in the art magazine, Artes De México, Chocolate: Cultivo y Cultura Del México Antiguo, a turkey would cost 200 beans, a rabbit was 30 beans and a slave was worth between 2,400 to 4,000 beans if that slave had the skills to sing and dance otherwise, the slave was worth 600 to 1,000 beans (Nondedeo).

In A Brief History of Chocolate, it states that Montezuma introduced Cortes to chocolate in a beverage form. It had a bitter spicy taste to it because sugar had not yet been introduced into chocolate. Cortes brought this chocolate beverage to Spain and then sugar was added to this beverage. During that time this chocolate beverage was considered a very elite drink because only the wealthy consumed it. Chocolate then spread throughout Europe (Feigl).

This is similar when immigrants bring their recipes from their native countries. The new food or beverage is introduced to the new land and eventually that food or beverage becomes mainstay in that new land. For example, Mexican, Italian and Chinese food are a part of the American diet. "American" food is a melding of all recipes from all nationalities. 
The cacao is similar to the cashew fruit in that its origin is from Mexico but was taken to West Africa by European colonizers. The cacao can only be harvested by hand because it is a delicate process and if done incorrectly may harm future cacao pods. The pods contain an edible fruit and this fruit surrounds the nibs or the beans inside the cacao pods. It too is edible and delicious, however, it is not harvested for consumption but used in preparation of the cacao beans. The fruit and beans are removed from the pods and are placed out in the sun for the fruit to ferment. The fermentation of the fruit gives the cacao its flavor and different cacao trees emit different flavors depending on the type of tree. Not all cacao trees are the same and artisanal chocolate makers are connoisseurs of the different varieties of cacao trees. (Cook)

The blown glass cacao pods were created to juxtapose them next to the earthenware ceramic pods. In the mediums of ceramic and glass, the perceived value of the glass is higher next to the ceramic. Metaphorically, the value of the earthenware is similar to the value of the manual laborer, whereas the perceived value of the glass is similar to the value of the cacao beans. In addition, the cacao pods symbolically refers to the migration journey. The cacao pods traveled from Mexico to Spain and then spread throughout Europe and globally. Chocolate is universally known and recognized due to its migration. 


\section{CONCLUSION}

The focus of my work has been to display the migration of the manual laborer in relationship to certain tropical foods those same laborers cultivated and harvested by hand. These same foods have a high value placed on them, even though the effort by the manual laborers to make the food mainstays in society has been perceived as low value.

In the future, I see myself further exploring the theme of multiculturalism and combining it with social commentary work. I will explore ways for the viewer to interact with future works of art. I know I am only but one person, but if I can at least bring awareness or start a dialogue pertaining to these issues, then I am satisfied. 


\section{REFERENCES}

Carr, Marilyn, Chains of Fortune: Linking Women Producers and Workers with Global Markets, Commonwealth Secretariat, 2004. 78. Print.

"Cashew Plant." Encyclopedia Britannica. N.p., 01 Jan. 2017. Web. 20 Apr. 2017. <https://www.britannica.com/plant/cashew>.

Cook, L. Russel, “Cacao.” Encyclopedia Britannica, N.p., 01 Apr. 2014

Fiegle, Amanda. "A Brief History of Chocolate." Smithsonianmag, N.p., 1 Mar. 2008. Web. 20 Apr. 2017. <http://www.smithsonianmag.com/artsculture/a-brief-history-of-chocolate-21860917/>.

Grynsztejn, Madeleine, "Voice of the Invisible". Tate. N.p., 1 Sept. 2007. Web. 20 Apr. 2017. http://www.tate.org.uk/context-comment/articles/voice-invisible

Johnson, Kirk. "Dish by Dish, Art of Last Meals.” The New York Times. N.p., 25 Jan. 2013. Web. 20 Apr. 2017. http://www.nytimes.com/2013/01/26/arts/design/the-last-supper-by-julie-green-at-

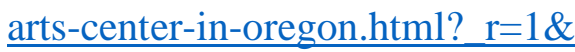

Keiren. “The Art of Henrique Oliveira.” Nifty Homestead. N.p., 6 May 2016. Web 20 Apr. 2017. https://www.niftyhomestead.com/blog/henrique-oliveira/ 
Leissle, Kristy. "What's Fairer than Fair Trade? Try Direct Trade with Cocoa Farmers." Yes! Magazine. N.p., 04 Oct. 2013. Web. 20 Apr. 2017. $<$ http://www.smithsonianmag.com/arts-culture/a-brief-history-of-chocolate21860917/>.

Nondedeo, Philippe. "Cacao in the Maya World: Feasts and Rituals." Artes De México: Chocolate Cultivo y Cultura Del México Antiguo Sept. 2011: 73-74. Print.

Palermo, Elizabeth, “Where do cashews come from?” Live Science, N.p., 30 Jun. 2014 Smiley, Lauren, "Farm Confessional, I'm an undocumented farm worker" Modern Farmer, N.p., 06 Nov. 2013. Web. 20 Apr. 2017. <http://modernfarmer.com/2013/11/farmworker-confessional/>.

Tanabe, Rosie, "Coconut." New World Encyclopedia, 7 Mar 2017, N.p., 19 Apr 2017. http://www.newworldencyclopedia.org/entry/Coconut 


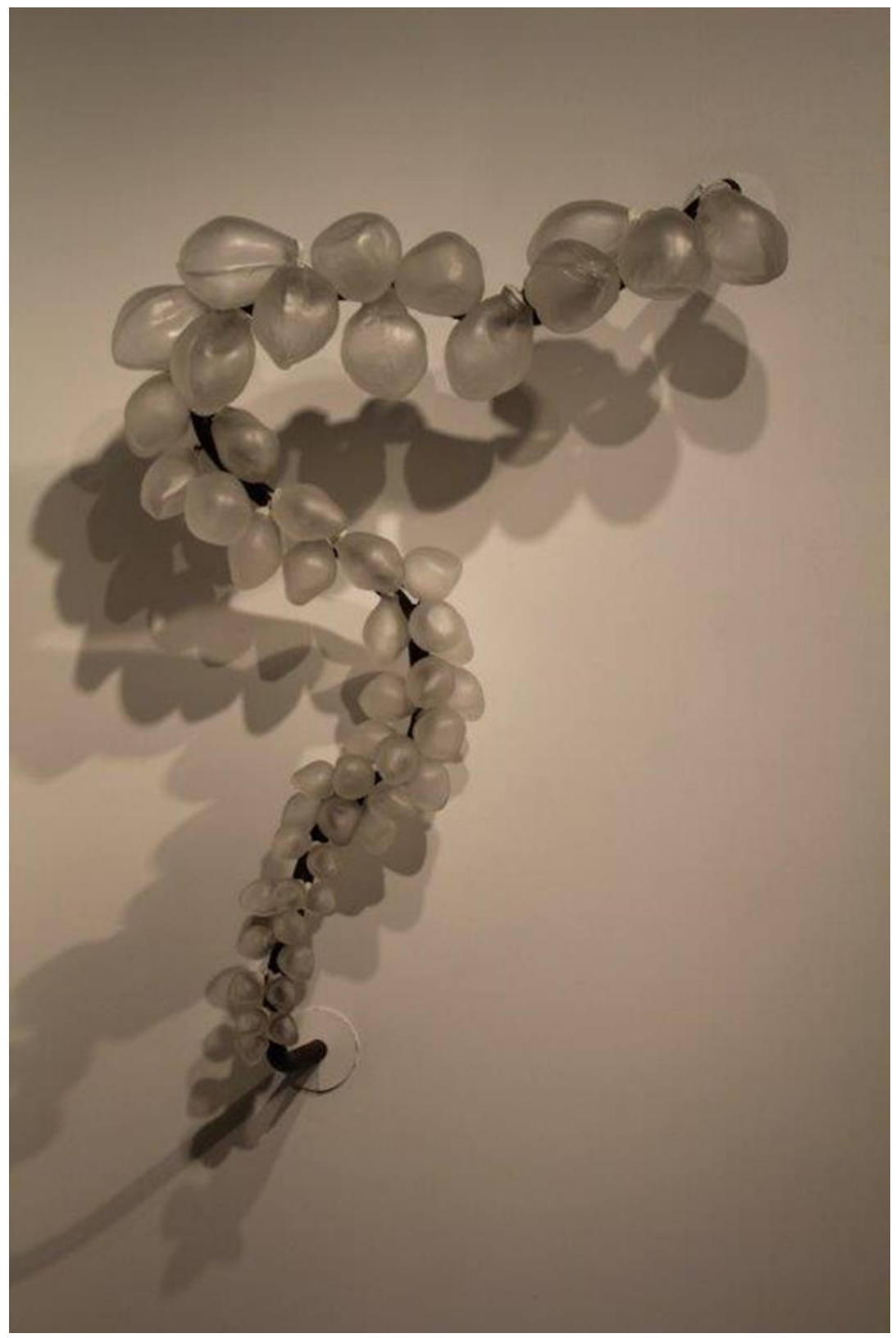

Poco a poco se raya el coco / Little by Little the Coconut is Shred,

Blown Glass, metal, 2017; 6.5' x 2.5' 


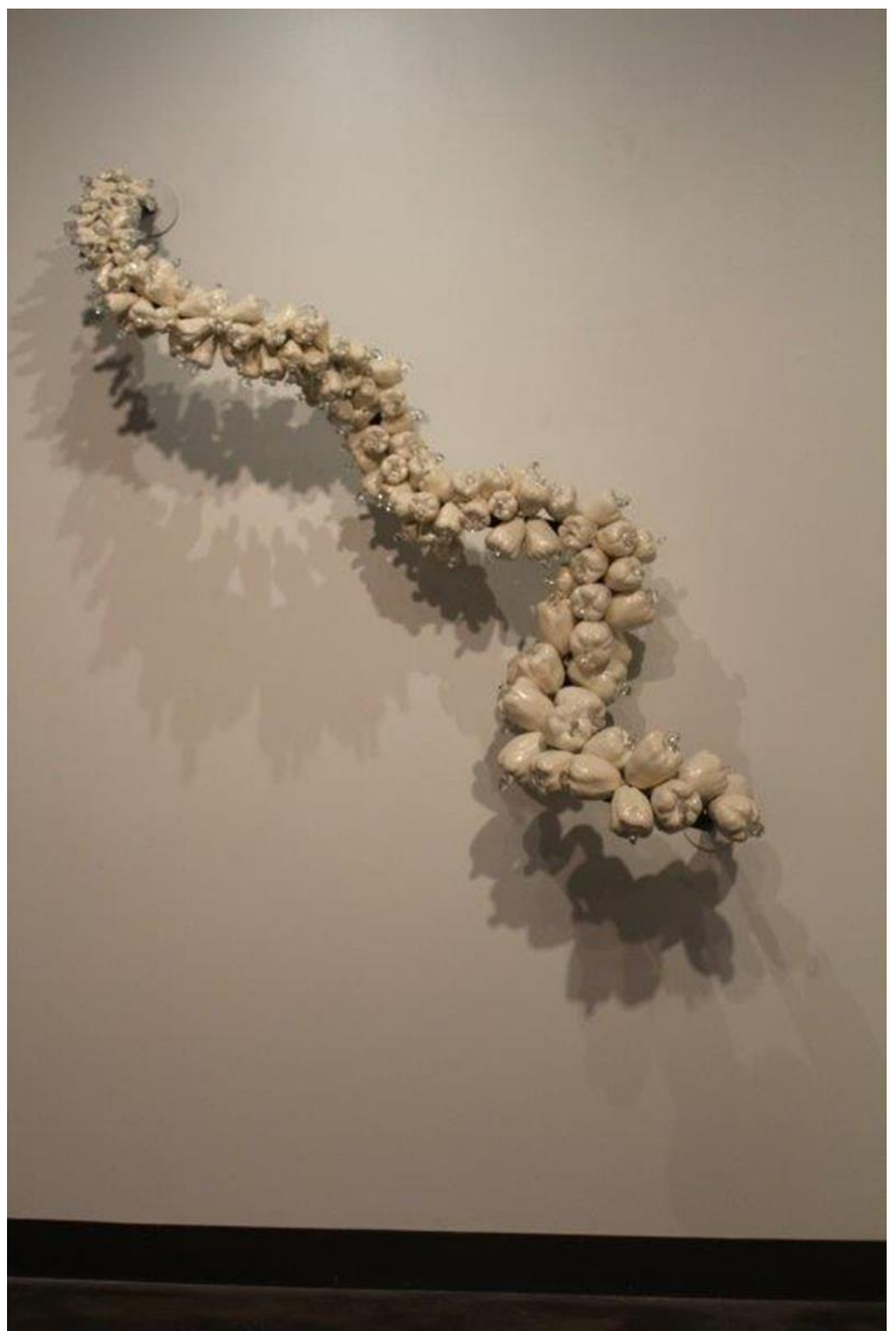

A mano / By Hand, Cast ceramics, glass and metal, 2017; 8.5' x 2.5' 


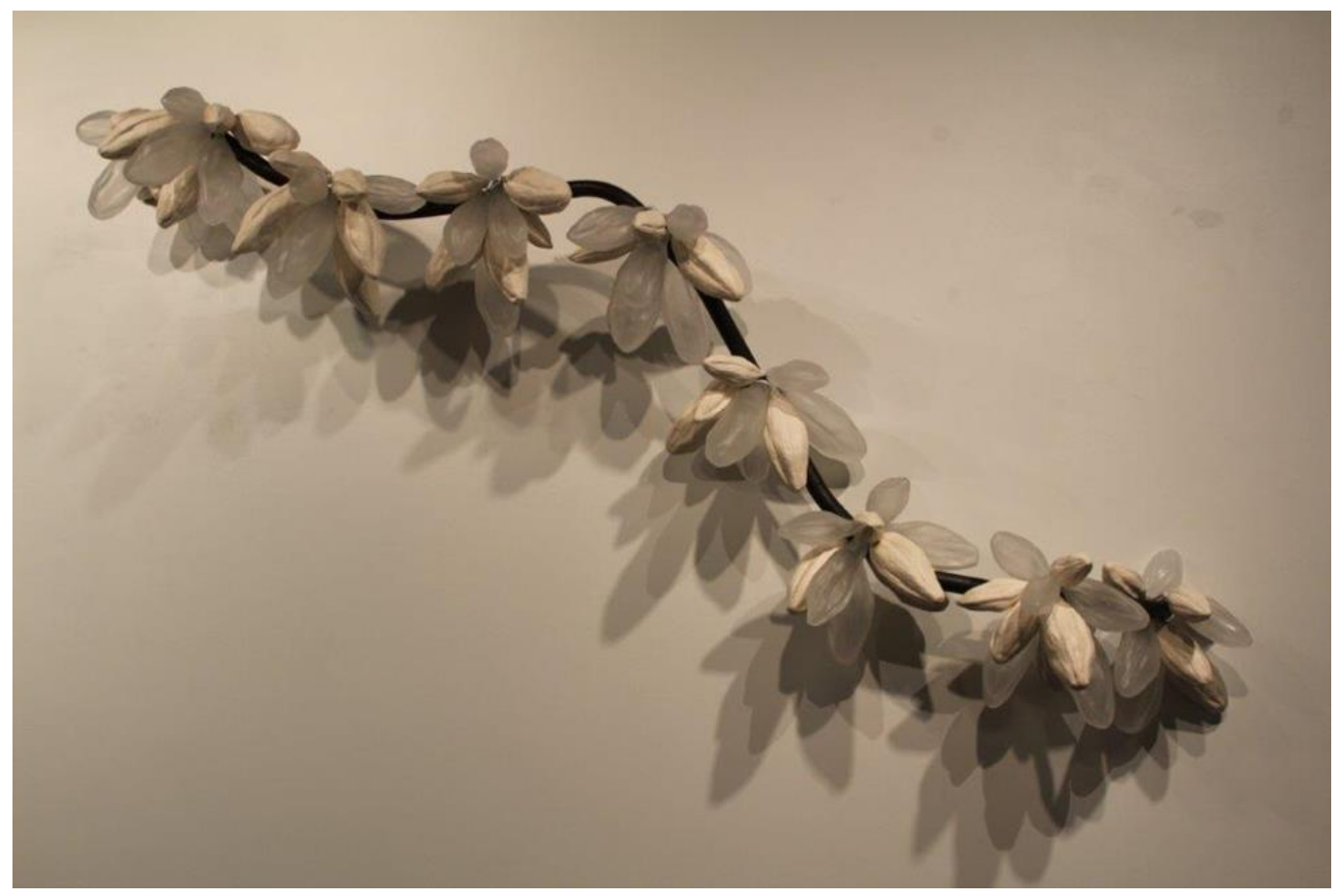

Agridulce / Bittersweet; Cast ceramic, blown glass and metal, 2017; 8.5' x 2.5' 


\section{CURRICULUM VITA}

NAME: $\quad$ Marie-Elena Ottman

ADDRESS: 4100 Bent Ridge $\mathrm{Ct}$

Crestwood, KY 40014

DOB: $\quad$ Republic of Panama - July 3, 1967

EDUCATION: $\quad$ Present - Masters of Fine Arts Candidate, University of Louisville 2004 BFA Ceramics, with Honors, University of Louisville

\section{PROFESSIONAL ACTIVITY:}

2016, Judge - Ceramics/Glass - Arts on the Green, La Grange, KY 2010-2015 Ceramic Program Director, Oldham County Schools Arts Center, Crestwood, KY

2015 Internship at Doors to Hope via University of Louisville - Teaching English through Art \& Bilingual Book Project

2015 Assistant to Mary Carothers - Connect/Disconnect art Installation

Waterfront, Louisville, KY

2015 Judge -Ceramics/Glass - Arts on the Green, La Grange, KY

2015 Judge - Animal Attraction Exhibit, Gallery 104, La Grange, KY

2014 Kentucky Crafted: The Market, Lexington, KY

2014 Artist in Residence - Hawthorne Elementary, Louisville, KY

2013 Coiled, Pinched and Paddled: Hand building Methods, Workshop at Appalachian Artisan Center, KY

2013 Visiting Artist, Jefferson Comm. \& Technical College, Louisville, KY

2013 Artist-in-Residence, Hawthorne Elementary, Louisville, KY

2012 Panelist; "Strategies: Where did we go from here?" University of Louisville

2012 Artist-in-Residence, Hawthorne Elementary, Louisville, KY

2012 Juror, Student Art Show, Jefferson Comm. \& Technical College

2010-2011 Artist-in-Residence, Oldham County Schools Arts Center

2011 Juror; Arts on the Common, Kettering, OH

2010 Kentucky Crafted, Architectural Directory

2010 Juried Member, Southern Artistry

2010 Artist-in-Residence, New Middletown Elementary, IN

2010 ArtTalk, Discuss my art and my process, Gallery 104, La Grange, KY 
2009 Kentucky Arts Council, Architectural Directory

2009 Art Slide Presentation, discuss my inspirations and work, Louisville Clay

2009 Coiled, Pinched \& Paddled: Contemporary \& Traditional Methods to Coil

Building, Workshop at Kentucky Museum of Art \& Craft

2009 Artist-in-Residence, Kentucky Museum of Art \& Craft

\section{SOLO EXHIBITIONS:}

2013 Marie-Elena Ottman: Nostalgic Creatures (May 2013) - Appalachian Artisan Center, Hindman, KY

2012 Marie-Elena Ottman: Nostalgia - Krantz Gallery, Jefferson Comm. \& Technical College, Louisville KY

2007 Marie-Elena Ottman: Ceremonial Vessels - Jane Morgan Studio \& Gallery, Louisville, KY

\section{SELECTED EXHIBITIONS:}

2016 Open Studio Weekend, Louisville, Visual Art Association \& UofL Hite Art Institute, Louisville, KY

2016 Blend 2016: An Exhibition of Latino Artists, Arts Place, Lexington, KY

2016 Beyond Borders, The Arts Council Southern Indiana, New Albany, IN

2016 Fantastic Fibers 2016, International Juried Exhibit-Yeiser Art Center,

Paducah, KY

2015 Artists in Our Midst, Kaviar Forge Gallery, Louisville, KY

2014 Consummate Craftsman, Owensboro Museum of Fine Arts, Owensboro, KY (Nov 2014.-Feb 2015)

2014 Open Studio Weekend, Louisville Visual Arts Association \& UofL Hite Art Institute, Louisville, KY

2013 Open Studio Weekend, Louisville Visual Arts Association \& UofL Hite Art Institute, Louisville, KY

2012 Making it: Now; Hite Art Institute, University of Louisville, KY

2012 Breaking the Mold: Louisville Clay 10th Anniversary; Weber Gallery, KY

2012 "Animal Attraction", Gallery 104, LaGrange, KY

2011 Collecting Kentucky Exhibit, Kentucky Museum of Art and Craft, KY

2010 Original Clay Group Holiday Pottery Show, Clifton Arts Center, KY

2010 "Bluegrass Biennial”, Morehead State University, Claypool-Young Art

Gallery, Morehead, KY

2010 18th San Angelo National Ceramic Competition, San Angelo Museum of

Fine Arts, San Angelo, TX

2010 “Animal Attraction", Gallery 104, LaGrange, KY

2009 "Holidaze", Owensboro Museum of Fine Arts, Owensboro, KY

2009 "Holidazzle Clay" Kentucky Museum of Art and Craft, Louisville, KY

2009 "Kentucky Bluegrass Music Festival”, KMAC at Water Tower, Louisville, $\mathrm{KY}$

2009 “Kentucky Experience Pavilion Exhibit”, Governor's Mansion, Frankfort, $\mathrm{KY}$ 
2009 “Arte Latino", Mills Pond House Gallery, St. James, NY

2009 "Go Ahead, Make my Clay", Gallery Janjobe, Louisville, KY

2009 Best of Louisville Clay, Kentucky Museum of Art \& Craft, Louisville, KY

2009 Artist Member Show, Kentucky Museum of Art \& Craft, Louisville, KY

2008 Exhibit of Ceramic Artworks, The Gallery on Pearl, New Albany, IN

2007 Handbuilt: Kentucky Clay Artists (NCECA), Artisan Center, Berea, KY

2007 ReWedged: 30 Years of Ceramics at the University of Louisville (NCECA), Louisville, KY

2005 Arts on the Green, Juried show, La Grange, KY

2005 Panama Canal Society Reunion Exhibit, Orlando, FL

2005 A Celebration of the Arts, Crestwood, KY

2004 New Lessons-New Work, Allen R. Hite Gallery, Louisville, KY

2004 B.F.A. Thesis Show, Allen R. Hite Gallery, Louisville KY

2004 NCECA “12”, Old RIS Warehouse, Indianapolis, IN

AWARDS:

2016 Notable Mention, Glass Art Society 4th Annual Juried Selected Catalogue, Graduate Level

2014-17 Cressman Scholarship

2012 First Place, Oldham County Fine Arts Show, Buckner, KY

2012 Second Place, Animal Attraction, Gallery 104, La Grange, KY

2010 Third Place, Bluegrass Biennial, Moorehead State University-Claypool-

Young Art gallery

2010 Third Place, Animal Attraction, Gallery 104, La Grange, KY

2009 Honorable Mention, Best of Louisville Clay, Kentucky Museum of Art \&

Craft

2006 Honorable Mention, Arts on the Green, Juried Show

2005 Third Place for 3D Division, Arts on the Green, Juried Show

2004 Allen R. Hite Scholarship

2003 Allen R. Hite Scholarship

\section{PUBLICATIONS:}

2016: Video interview in Spanish for Acentos.

https://www.youtube.com/watch?v=uKdlj0Hkouk

2016: Radio interview on U of L Today with Mark Hebert and Chris Reitz, promoting Open Studio Weekend, my work and my experiences as one of three inaugural MFA Candidates at $\mathrm{U}$ of $\mathrm{L}$

2011 "What's Happening in Oldham County" Artist in Residence OCSAC

2010 "Ceramics mural project inspires creativity, school spirit at Harmony

Elementary", The Courier-Journal

2010 "A Little Culture", The Courier-Journal

2010 "Artist in Residence brings Art to Oldham County", RoundAbout

2010 "Panama Native will share Her Craft as Artist in Residence", The CourierJournal 
2008 "People, Places, Events", Art-to-Art Palette, Print Journal Exhibition 2008 Featured Artist, "Kentucky Life", KET-PBS aired 11/15/2008

2008 Featured Artist, "Main Street - Everyday Art" WKYU-PBS, aired 3/2008

2008 Featured Artist, The Potter's Shed, online Journal

2007 Featured Artist, The Oldham Era

2007 Featured Artist, The Courier-Journal

2007 Featured Artist, The Oldham Era

2007 Featured Artist, The Oldham Era

2007 Featured Artist, "Kentucky Bluegrass \& Back Roads", aired 1/2007

2006500 Animals in Clay, Contemporary Expressions of the Animal Form, Lark

Books Publication

2006 Featured artist, The Courier-Journal

\section{PERMANENT AND PRIVATE COLLECTIONS:}

Included in the Permanent Collection of the Kentucky Museum of Arts and Crafts as well as numerous private collections throughout the United States and the Republic of Panama. 